\title{
Pulmonary manifestations of Behçet's disease
}

\author{
F Erkan, A Gül, E Tasali
}

\begin{abstract}
History
Behçet's disease is a chronic inflammatory disorder of unknown aetiology characterised by recurrent attacks. Although the triple symptom complex of oral and genital ulcerations with uveitis was reported by Hippocrates and other authors who attributed the symptom triad to major infections, Hulusi Behçet, a Turkish dermatologist, discarded the association with other illnesses and was the first to delineate the disease that now bears his name. ${ }^{1}$ Clinical manifestations additional to this triad were described later including involvement of the skin, joints, large vessels, lung, brain, gastrointestinal and genitourinary tracts (table 1$).^{2-6}$ It is now recognised as a multisystem disease with vasculitis as the main pathological finding. ${ }^{6-10}$
\end{abstract}

\section{Diagnosis}

Since Behçet's disease does not have pathognomonic symptoms or laboratory findings, the diagnosis is made on the basis of the criteria proposed by the International Study Group for Behçet's disease in 1990 (table 2). ${ }^{11}$ According to the criteria, recurrent oral ulceration must be present and at least two of the following: recurrent genital ulceration, eye lesions, skin lesions, or a positive pathergy test (development of a papule or pustule following a needle prick to the skin, as in table 2).

\section{Epidemiology}

Although Behçet's disease has a worldwide distribution, most cases cluster along the ancient Silk Road which extends from far eastern Asia to the Mediterranean basin (table 3). ${ }^{12-18}$ The highest prevalence rate was reported from Turkey as $80-370$ per 100000 . The prevalence ranges from two to 30 cases per 100000 in

Table 1 Frequency of clinical manifestations in Behçet's disease $^{8912}$

\begin{tabular}{ll}
\hline Lesion & Frequency \\
\hline Oral ulcers & $96-100$ \\
Skin lesions & $40-50$ \\
$\quad$ Folliculitis & $25-80$ \\
$\quad$ Erythema nodosum & $10-50$ \\
$\quad$ Positive pathergy test & $65-90$ \\
Genital ulcers & $35-70$ \\
Eye lesions & $30-80$ \\
Arthritis & $10-50$ \\
Neurological involvement & $5-60$ \\
Gastrointestinal involvement & $5-30$ \\
Vascular involvement & $1-8$ \\
Pulmonary involvement & \\
\hline
\end{tabular}

other Asian countries, with lower figures in Europe and the USA. The age of disease onset is usually in the second or third decade of life and the male to female ratio is reported to be almost equal. However, the disease runs a more severe course in men and in those with an onset before 25 years of age. ${ }^{7-10}$

\section{Genetic association}

Several studies have found a strong association between the risk of developing Behçet's disease and HLA-B51. ${ }^{19}{ }^{20}$ The relative risk of the disease among carriers of this allele is up to 13.3 in Turkey compared with 1.3 in the USA. ${ }^{1021}$ The association of HLA-B51 positivity with eye disease and a more severe clinical course is controversial. ${ }^{22}$

\section{Pulmonary involvement}

More than 200 cases of Behçet's disease with pulmonary involvement have been reported in the literature. ${ }^{23-50}$ The pulmonary arteries are

Table 2 International Study Group criteria for the diagnosis of Behçet's disease

In the absence of other clinical explanations patients must have:

(1) Recurrent oral ulceration (aphthous or herpetiform) observed by the physician or patient recurring at least three times in one 12 month period + two of the following:

(2) Recurrent genital ulceration

(3) Eye lesions:

- anterior uveitis;

- posterior uveitis (cells in the vitreous observed by slit lamp examination); or

- retinal vasculitis observed by an ophthalmologist.

(4) Skin lesions:

- erythema nodosum,

- pseudofolliculitis;

- papulopustular lesions or acneiform nodules in post-adolescent patients not on corticosteroids

(5) Positive skin pathergy test read by a physician at 48 hours - that is, a $2 \mathrm{~mm}$ erythematous papule or pustule at the prick site 48 hours after the application of a sterile hypodermic $20-22$ gauge needle which obliquely penetrated avascular antecubital skin to a depth of $5 \mathrm{~mm}$.

Table 3 Epidemiological data for Behçet's disease

Rheumatology,

Department of

Internal Medicine,

Istanbul Medical

Faculty

A Gül

Correspondence to: Dr F Erkan, Gögüs Hastaliklari Anabilim Dali, Istanbul Tip Fakültesi, 34390 Çapa-Istanbul, Turkey feyzaerkan@superonline.com

\begin{tabular}{lll}
\hline & $\begin{array}{l}\text { Prevalence rate } \\
(\text { (100 000) }\end{array}$ & Reference \\
\hline Turkey & $80-370$ & 6 \\
Japan & $7-8.5$ & 7 \\
Other Asian countries & $2-30$ & 8 \\
UK & $0-64$ & 9 \\
Germany & & \\
$\quad$ German natives & $0.42-0.55$ & 10 \\
$\quad$ Turkish immigrants & 21 & 10 \\
\hline
\end{tabular}




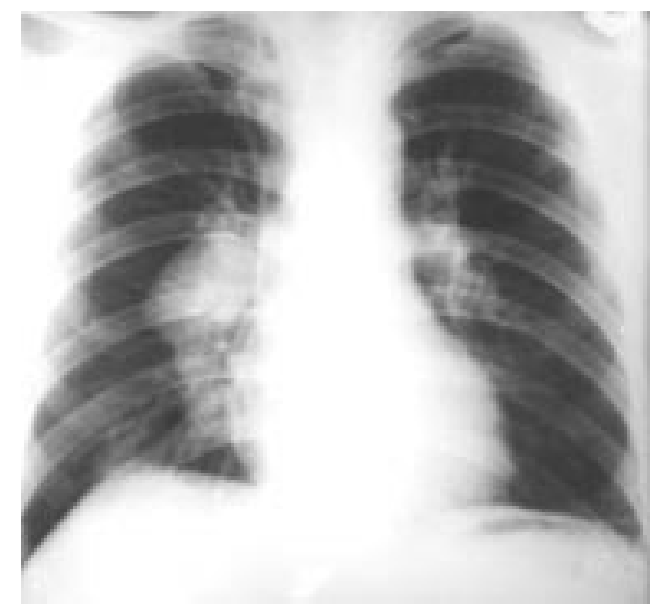

Figure 1 Chest radiograph of a patient with an aneurysm of the right pulmonary artery. (Courtesy of Dr T Ece).

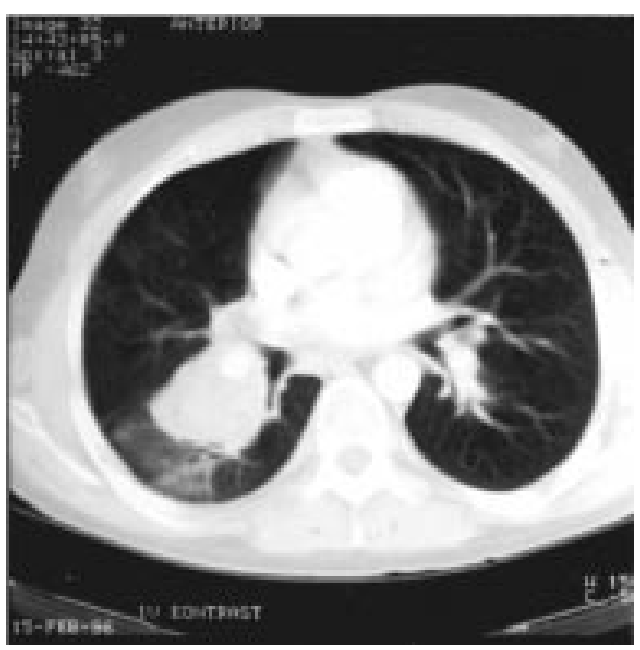

Figure 2 Computed tomographic scan of a patient showing a thrombosed aneurysm of the right pulmonary artery. The fuzzy contour of the aneurysm wall and perianeurysmal consolidation are caused by an acute haemorrhage. (Courtesy of $\operatorname{Dr} A$ Tunaci).

the second most common site of arterial involvement, preceded by the aorta. Aneurysms are more common than thrombosis.

Pulmonary artery aneurysms, arterial and venous thrombosis, pulmonary infarction, recurrent pneumonia, bronchiolitis obliterans organised pneumonia, and pleurisy are the main features of pulmonary involvement in Behçet's disease. The true prevalence of the pulmonary manifestations in Behçet's disease is unknown because no prospective study has evaluated all pulmonary symptoms in an unselected group of patients. The reported prevalence has ranged from $1 \%$ to $7.7 \% .^{2}{ }^{40}$

PULMONARY ARTERY ANEURYSMS

Pulmonary artery aneurysms affect mainly young men. Haemoptysis of varying degrees (up to $500 \mathrm{ml}$ ) is the most common and predominant symptom. Rupture of an aneurysm with erosion into a bronchus and the development of in situ thrombosis from active vasculitis have been suggested as explanations for the haemoptysis. ${ }^{23-50}$ Sudden hilar enlargement or the appearance of polylobular and round opacities on the chest radiograph can

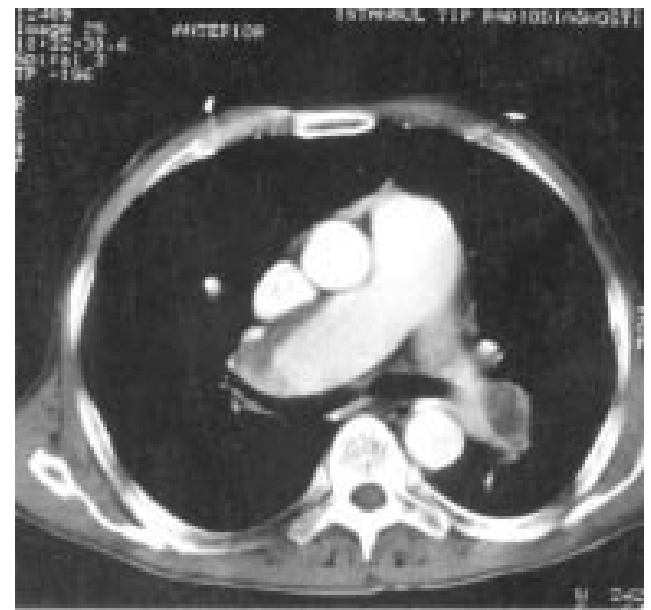

Figure 3 Computed tomographic scan showing thrombosed pulmonary artery aneurysms. (Courtesy of Dr A Tunaci).

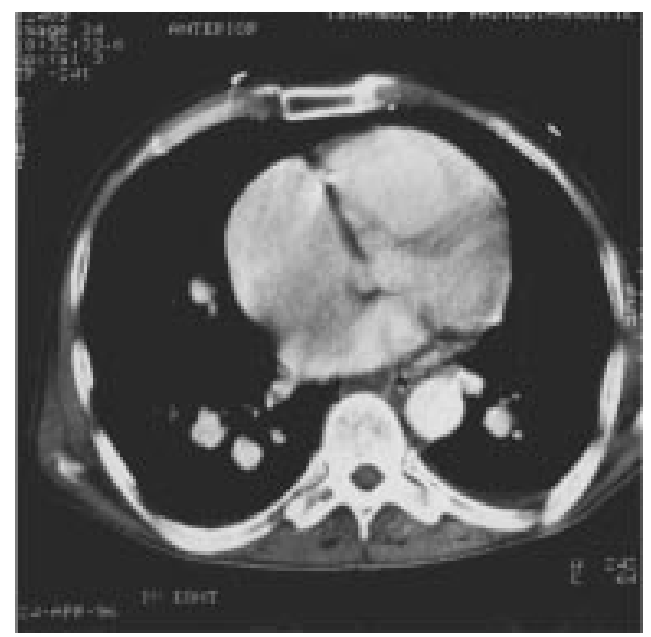

Figure 4 Computed tomographic scan showing multiple aneurysms of different branches of the pulmonary arteries bilaterally. (Courtesy of Dr A Tunaci).

represent pulmonary artery aneurysms (fig 1). When associated with an acute episode of haemoptysis they appear poorly marginated; otherwise, they have a distinct outline. ${ }^{40-50}$ Helical computed tomography is currently the method of choice for the diagnosis because it provides excellent vascular images with only a small quantity of contrast material. ${ }^{36-50}$ Aneurysms are seen as saccular or fusiform dilatations which show homogeneous contrast filling simultaneously with the pulmonary artery (figs 2, 3, 4). Pulmonary artery aneurysms are located most frequently in the right lower lobar arteries, followed by the right and left main pulmonary arteries. ${ }^{38}$ In this study the diameter of the aneurysms ranged from 1 to $7 \mathrm{~cm}$ and between two and seven aneurysms have been detected in the same patient. Magnetic resonance imaging is also helpful in the diagnosis of pulmonary artery aneurysms. ${ }^{51}{ }^{52}$ Although no comparative studies are available, it is considered to be less sensitive than helical computed tomography in demonstrating small aneurysms. Digital substraction angiography has also been used in the diagnosis but it may be 


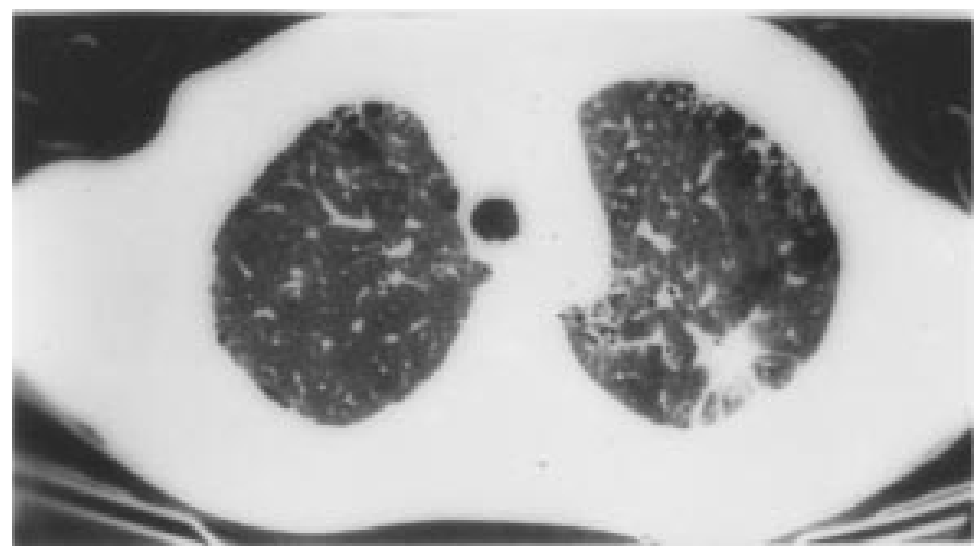

Figure 5 Computed tomographic scan showing a focal non-segmental infiltrate in the left subpleural region in a patient with Behçet's disease. (Courtesy of Dr A Tunaci).

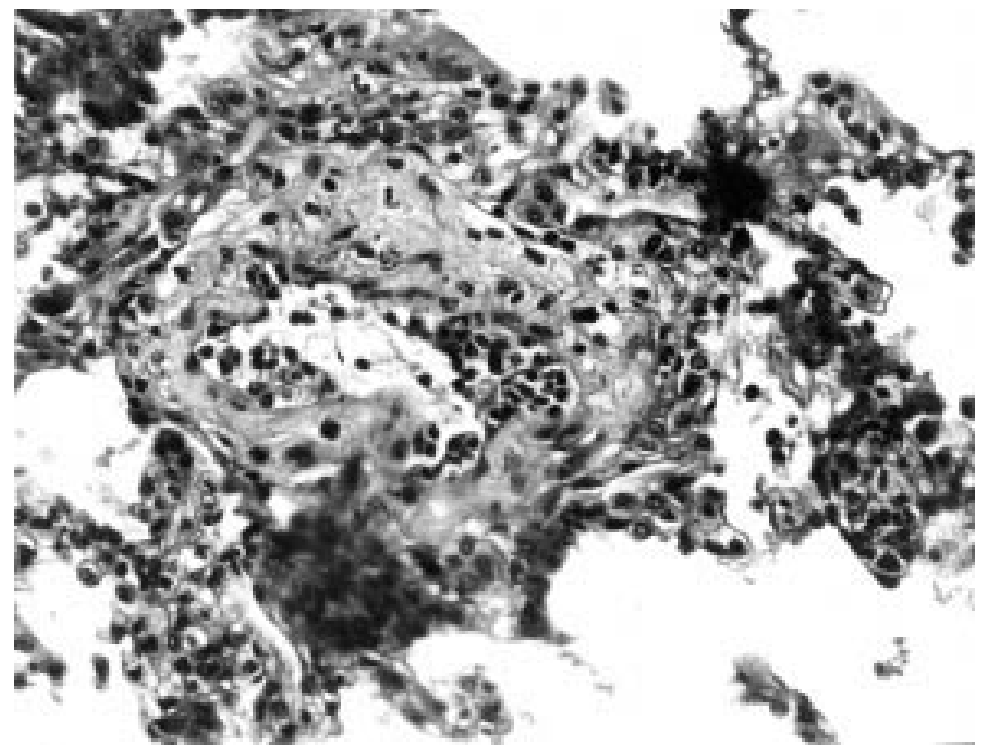

Figure 6 Photomicrograph of the histopathology of a pulmonary vessel from a pneumonectomy sample from a patient suffering major haemoptysis due to Behcet's disease showing a neutrophilic vasculitis. Stain: HEE, $\times 310$. (Courtesy of Dr D Yilmazbayhan).

inadequate if aneurysms or vessels are completely thrombosed. ${ }^{37384852}$ Imaging techniques such as aortography, venography, and pulmonary angiography are no longer used as they carry a higher risk of complications. The frequency of such complications with digital substraction angiography is unknown. In one case report radionuclide angiography showed alterations in pulmonary artery blood flow as clearly as did subsequent contrast pulmonary angiography..$^{53}$ Normal or aneurysmally dilated pulmonary arteries frequently become obliterated by large thrombi. On chest radiography this may result in hyperlucent areas of the lung supplied by these vessels. Computed tomographic scanning can show a mosaic pattern of variable attenuation reflecting nonhomogeneous perfusion. ${ }^{38}$ Ventilationperfusion lung scans show bilateral, well defined, mismatched areas. ${ }^{35}$ Although deep venous thrombosis of the lower extremities frequently accompanies pulmonary artery aneurysms, pulmonary thromboembolism is very rare in Behçet's disease because the thrombi in inflamed veins are strongly adherent. ${ }^{36}$
PULMONARY PARENCHYMAL FINDINGS

Atelectasis, volume loss, wedge shaped, or linear shadows, ill defined, nodular or reticular opacities have been described in Behçet's disease with or without pulmonary artery aneurysms (fig 5). ${ }^{23-48}$ These findings are generally accepted as foci of pulmonary haemorrhage and/or infarcts. However, the pathological correlation of the parenchymal opacities has only been documented in a few cases. ${ }^{26} 3754$ A recent case report reported prominent clinical, radiological, and pathological findings of organising pneumonia associated with pulmonary artery aneurysms. ${ }^{54}$ Organising pneumonia may accompany various collagen vascular diseases including systemic lupus erythematosus and systemic vasculitides such as Wegener's granulomatosis. ${ }^{55}$ Patients with secondary organising pneumonia have a worse prognosis than cryptogenic or primary cases. ${ }^{57}$ In another patient with Behçet's disease and peripheral non-segmental pulmonary infiltrates, eosinophilic pneumonia was found on transbronchial biopsy. ${ }^{37}$

\section{OTHER THORACIC MANIFESTATIONS OF BEHCET'S} DISEASE

Involvement of major veins including occlusion of the superior vena cava is a more prevalent finding than arteritis. Thrombosis of the innominate and subclavian veins may accompany superior vena caval occlusion. ${ }^{58-61} \mathrm{Mag}-$ netic resonance imaging is the suggested diagnostic method. Pseudoaneurysms of the aortic arch as well as the subclavian and coronary arteries have been described in Behçet's disease. ${ }^{62}{ }^{63}$ Mediastinal mass, mediastinitis, chyloptysis, and pleurisy are other associated conditions. ${ }^{32} 374064$ Pleural effusion may result from vasculitis of the pleura or thrombosis of the superior vena cava. ${ }^{37}$

\section{Pathology}

The central feature of the histopathology of Behçet's disease is systemic vasculitis and perivascular inflammatory infiltrates. ${ }^{56}$ The vasculitis can involve large, medium, and small vessels of both the arterial and venous circulation. Inflammatory infiltrates may be granulocytic, mononuclear, or mixed (fig 6). There is a tendency to thrombus formation with thrombi in the lumen of vessels showing features of inflammation and focal areas of lymphocytes. Pathologically, the pulmonary artery aneurysms have perivascular infiltrates around the vasa vasorum, marked intimal thickening with degenerative changes in the elastic lamina, thrombotic occlusion, and recanalisation as well as fresh thrombi. ${ }^{32} 54$

\section{Natural history and prognosis}

The natural history of Behçet's disease is one of exacerbations and remissions. Male sex and young age of onset are markers of a more severe prognosis. Pulmonary artery aneurysm formation has a very poor prognosis and is one of the leading causes of death in Behçet's disease; $30 \%$ of patients with this condition die within 2 years. ${ }^{32}{ }^{40}$ Mean survival after the onset of haemoptysis was reported to be about 10 
months in one study of patients with Behçet's disease and pulmonary artery aneurysms. ${ }^{36} \mathrm{~A}$ more recent follow up study of computed tomographic findings in 13 patients receiving immunosuppressant treatment showed complete disappearance or regression of pulmonary artery aneurysms during 3-42 (mean 21) months of treatment. ${ }^{38}$ Disappearance and regression of the aneurysm were preceded by thrombus formation. After treatment the thrombi regressed and pulmonary artery aneurysms disappeared. Massive bleeding has been reported in patients receiving immunosuppressant treatment, although a partial remission was achieved. ${ }^{36} 3854$

\section{Management}

\section{IMMUNOSUPPRESSANT TREATMENT}

Empirical anti-inflammatory and/or immunosuppressive drugs tailored to the severity of the disease remain the mainstay of treatment. ${ }^{65-67} \mathrm{~A}$ combination of cyclophosphamide and methylprednisolone is used most frequently for patients with pulmonary artery aneurysms, ${ }^{7867}$ although no controlled trial has assessed the efficacy of this combination. For patients with pulmonary artery aneurysms we give cyclophosphamide $1000 \mathrm{mg}$ monthly as intravenous pulses or $2 \mathrm{mg} / \mathrm{kg} /$ day orally with oral methylprednisolone $1 \mathrm{mg} / \mathrm{kg}$. For patients with severe haemoptysis we start with intravenous pulses of methylprednisolone 500-1000 $\mathrm{mg}$ for 3 days together with pulsed cyclophosphamide. ${ }^{7864}$ The prednisolone dose is then tapered depending on the clinical response, while the cyclophosphamide regimen is continued for at least 1 year after complete remission when it is frequently switched to azathioprine. ${ }^{35} 363840$ Cylosporin combined with coumarin was reported to be successful in a patient with a single pulmonary artery aneurysm ${ }^{34}$ and FK506 was used with good results in a patient with pulmonary infiltrates. ${ }^{68}$ Double blind controlled trials are needed to assess the efficacy and long term effects of currently used and new immunosuppressant drugs for eye lesions and/or life threatening complications in Behçet's disease.

\section{THROMBOLYTIC AND ANTICOAGULANT \\ TREATMENT}

Haemoptysis in Behçet's disease frequently leads to the misdiagnosis of pulmonary thromboembolism due to the frequent presence of a peripheral deep vein thrombosis and an abnormal ventilation-perfusion scan. Anticoagulation carries significant risks for patients with pulmonary artery aneurysms and must be used cautiously and only after systemic immunosuppressant treatment has been given. ${ }^{40}$ If thrombi are not extensive, antiplatelet treatment with, for example, low dose aspirin, is probably sufficient. $^{35}{ }^{40}$ Thrombolytic treatment with urokinase was tried in one patient with a thrombosed pulmonary artery aneurysm ${ }^{69}$ and streptokinase was given to a patient with superior vena cava syndrome. ${ }^{60}$ There was no evidence of new thrombotic episodes over the subsequent 2 year follow up period. ${ }^{69}$ Both patients were also receiving immunosuppressive treatment so the risks and efficacy of thrombolytic treatment is difficult to assess. There are no controlled studies of anticoagulants or antiplatelet aggregation therapy and there is a lack of consensus on their use.

Clinical trials are needed to address the place of these drugs in the management of thrombotic disease in these patients.

\section{EMBOLISATION}

Embolisation of a pulmonary artery aneurysm was attempted in one patient with massive bleeding. ${ }^{70}$ The size and number of aneurysms, the presence of superior or inferior vena caval occlusion, and the potential complication of severe bleeding are the main limitations to the use of embolisation in Behçet's disease.

\section{SURGERY}

In cases of massive haemoptysis urgent surgical resection may be necessary. The main problem facing the vascular surgeon is the $25 \%$ incidence of recurrent anastomotic aneurysms after both inlay graft repair and patching. ${ }^{71-74}$ False aneurysms and arteriovenous fistulae are also common at sites of previous iatrogenic trauma. Perioperative steroid cover has been suggested to reduce the risk of complications.

In conclusion, therefore, the mainstay of treatment in Behcet's disease is immunosuppressant therapy as in other severe vasculitides. Other treatment modalities should be used only in combination with this therapy and as palliative measures for specific complications.

\section{Pathogenesis}

The aetiology of Behçet's disease is unknown. Clinical observations and laboratory investigations support the concept that immunological mechanisms induced by microbial pathogens occur in genetically susceptible individuals. ${ }^{75}$

Although the majority of patients with Behçet's disease have no family history, a familial clustering can occur. Recent studies have shown that the risk of developing Behçet's disease by siblings of index patients is increased compared with the general population. Sibling risk ratio $(\lambda \mathrm{s}$, the ratio of sibling prevalence to population prevalence of disease) of Behçet's disease was reported to be 11.4-52.5 in Turkey, supporting the concept of an important genetic influence. ${ }^{76}$

The association of HLA-B51 with Behçet's disease is the strongest finding supporting the contribution of genetics to the pathogenesis of the disease. ${ }^{19} 20$ It remains to be clarified whether HLA-B51 has a direct role in the pathogenesis or whether this association reflects linkage disequilibrium with a disease associated susceptibility gene located near the HLA-B locus. Microsatellite polymorphism studies have identified a strong association of Behçet's disease with MHC class I Chain related gene A (MICA), which is located $\overline{4} 6 \mathrm{~kb}$ centromeric to HLA-B. ${ }^{77}$ However, HLA-B51 still shows the strongest association with Behçet's disease among the various polymorphisms in and around the critical region between HLA-B and MICA, and it is difficult to assess the individual supplementary effects of MICA or other neighbouring genes on 
HLA-B51 carrying haplotype. ${ }^{78} 79$ On the other hand, family studies indicate that the contribution of the HLA-B locus (HLA-B51) to the overall genetic susceptibility to Behçet's disease is less than $20 \%{ }^{80}$ Identification of other susceptibility loci is required.

Non-specific hyperreactivity is an important feature of Behçet's disease. The classical example is the skin pathergy reaction in which a papule or pustule occurs following a simple needle prick to the skin, similar to those appearing spontaneously in the disease..$^{81}$ This increased responsiveness to minor trauma or other stimuli is not unique to the skin, and the phenomenon can be seen at other sites or even at the cellular level as an upregulated inflammatory response. ${ }^{82}$ Increased expression of several cytokines from lymphocytes and monocytes has been reported..$^{83-87}$ Oversecretion of the Th1 type proinflammatory cytokines such as interleukin 2 (IL-2) and interferon $\gamma$ (IFN $\gamma$ ) is prominent, especially during the active phase of the disease. ${ }^{86}{ }^{87}$ Increased secretion of IL-1, IL-6, tumour necrosis factor $\alpha(\mathrm{TNF} \alpha)$ and IL-8 from monocytes following lipopolysaccharide stimulation compared with controls can also be observed, even in patients with inactive disease, and immunosuppressant drugs might not suppress this lymphocyte hypersensitivity as demonstrated by increased IFN $\gamma$ production in response to bacterial antigens in vitro. ${ }^{82} 83$

Activation of neutrophils with increased chemotaxis and superoxide generation has long been suggested as the main pathogenetic mechanism in Behçet's disease. ${ }^{75} 8889$ Increased production of some cytokines such as IL-8, $\mathrm{TNF} \alpha$, and IL-1 from lymphomononuclear cells, neutrophils, and/or endothelial cells may have a regulatory role in neutrophil function and might be responsible for this primed state. A similar neutrophil hyperactivity after fMLP stimulation was the only abnormal finding in HLA-B51 transgenic mice, and enhanced superoxide generation has been observed in HLA-B51 positive healthy controls. ${ }^{89} 90$ The relationship between HLA-B51 and neutrophil function remains to be clarified.

Recent studies point to a central role for the $\mathrm{T}$ cell mediated immune response in the pathogenesis of Behçet's disease. ${ }^{82 ~ 84-879192}$ Oligoclonal $\mathrm{T}$ cell expansions correlate with clinically active disease, supporting the view that an antigen driven immune response contributes to its immunopathogenesis. ${ }^{84}$ Several microbial agents, especially herpes simplex virus and certain strains of streptococci, have been claimed to induce the manifestations of Behçet's disease. A unifying hypothesis suggests that certain epitopes of microbial heat shock proteins (hsp) are putative antigens, triggering a specific immune response and producing a "cross reacting" inflammatory reaction. ${ }^{92}$ An increased $\mathrm{T}$ cell response has been shown against four peptides derived from $65 \mathrm{kD}$ mycobacterial hsp and their human homologues in British, Japanese, and Turkish patients with Behçet's disease. ${ }^{8492} 93$ A subset of $\gamma \delta+T$ cells is increased in Behçet's disease and may have a regulatory role in response to these peptides. $^{93-95}$ The hsp peptides cause uveitis in rats, and an association between a $\mathrm{T}$ cell proliferative response to one of the human $60 \mathrm{kd} \mathrm{hsp}$ peptides and the presence of ocular lesions has been reported in patients with Behçet's disease. ${ }^{84} 96$

Hormonal factors may also have a place in the pathogenesis of Behçet's disease. Although the number of men and women affected is similar in many series, men tend to have more severe disease. ${ }^{97} 98$ Acneiform skin lesions of Behçet's disease cannot be differentiated clinically or histologically from ordinary acne seen in cases of excess androgen. ${ }^{99}$ Detailed hormonal studies are needed to understand the contribution of sex hormones to the expression and severity of Behçet's disease.

\section{Prospective studies}

New diagnostic methods are helping to show the full clinical picture of Behçet's disease and to document some of the rarer manifestations such as parenchymal lung involvement and gastrointestinal disease.

Whole genome screening in multicase Behçet's disease families and association studies for candidate genes in cases and controls would help to identify other susceptibility genes. Elucidation of pathogenetic mechanisms may help to develop better therapeutic modalities-for example, the studies suggesting an important role for hsp derived peptides in immunological activation in Behçet's disease are being followed by experimental studies to try to induce tolerance using hsp peptides.

1 Behçet $H$. Über rezidivierende, aphtöse, durch ein Virus verursachte Geschwüre am Mund, am Auge und an den Genitalien. Dermatologische Wochenschr 1937;105:1152-7.

2 O'Duffy JD, Carney JA, Deodhar S. Behçet's disease. Report of 10 cases, three with new manifestations. Ann Intern Med 1971;75:561-70.

3 Chajek T, Fainaru M. Behçet's disease, report of 41 cases and a review of the literature. Medicine 1975;54:179-96.

4 Shimizu T, Ehrlich GE, Inaba G, et al. Behçet's disease. Semin Arthritis Rheum 1979;8:223-60.

5 Lakhanpal S, Tani K, Lie JT, et al. Pathologic features of Behçet's syndrome. Hum Pathol 1985;16:790-5.

6 Matsumoto T, Uekusa T, Fukuda Y. Vasculo-Behçet's Matsumoto T, Uekusa T, Fukuda
disease. Hum Pathol 1991;22:45-51.

7 Yazici H, Yurdakul S, Hamuryurdan V. Behçet's syndrome. Curr Opin Rheumatol 1999;11:53-7.

8 Hamuryudan V, Yurdakul S, Yazici H. Behçet's syndrome. Rheumatol Eur 1997;26:31-3.

9 Kaklamani VG, Vaiopoulos G, Kaklamani PG. Behçet's disease. Semin Arthritis Rheum 1998;27:197-217.

10 Sakane T, Takeno M, Suzuki N, et al. Behçet's disease. $N$ Engl F Med 1999;314:1284-91.

11 International Study Group for Behçet's Disease. Criteria for diagnosis of Behçet's disease. Lancet 1990;335:1078-80.

12 Zouboulis CC. Epidemiology of Adamantiades. Behçet's disease. Ann Med Interne 1999;150:488-99.

13 Yurdakul S, Günaydin I, Tüzün Y, et al. The prevalance of Behçet's syndrome in a rural area in Northern Turkey. $\mathcal{F}$ Rheumatol 1988;15:820-2.

14 Yamamoto S, Toyokawa H, Matsubara J, et al. A nation-wide survey of Behçet's disease in Japan. Ұpn f Opthalmol 1974; 18:282-90.

15 Hirohata T, Kuratsune M, Nomura A, et al. Prevalence of Behçet's syndrome in Hawaii. Hawaii Med $\mathcal{F}$ 1975;34:2446.

16 Chamberlain MA. Behçet syndrome in 32 patients in Yorkshire. Ann Rheum Dis 1977;36:491-9.

7 O'Duffy JD. Summary of International Symposium on Behçet's disease. F Rheumatol 1978;5:229-33.

18 Zouboulis, Kötter I, Djawari D, et al. Epidemiological features of Adamantiades Behçet's disease in Germany and in Europe. Yonsei Med F 1997;38:411-22.

19 Ohno S, Ohguchi M, Hirose S, et al. Close association of HLA-Bw51 with Behçet's disease. Arch Ophthalmol 1982; 100:1445-58

20 Mizuki N, Inoko H, Ohno S. Pathogenic gene responsible for the predisposition to Behçet's disaese. Intern Rev Immunol $1997 ; 14: 33-48$.
not

21 Yazici H, Chamberlain A, Schreuder I, et al. HLA antigens in Behçet's disease: a reappraisal by a comparative study of Turkish and British patients. Ann Rheum Dis 1980;39:344-8. 
22 Zouboulis CC, Büttner P, Diawari D, et al. HLA-class I antigens in German patients with Adamantiades-Behçet's disease and correlation with clinical manifestations. In:
Wechsler B, Godeau P, eds. Behcet's disease. Amsterdam: Excerpta Medica 1993:175-80.

23 Decroix AG. Thoracic manifestations in Behçet's syndrome. Thorax 1969;24:380.

24 Davies JD. Behçet's syndrome with haemoptysis and pulmonary lesions. F Pathol 1973;109:351-6.

25 Cadman EC, Lundberg WB, Mitchell MS. Pulmonary manifestations in Behçet syndrome. Arch Intern Med 1976; 136: $944-7$.

26 Petty TL, Scoggin CH, Good JD. Recurrent pneumonia in Behçet's syndrome. FAMA 1977;238:2529-30.

27 Gamble CN, Wiesner KB, Shapiro RF, et al. The immune complex pathogenesis of glomerulonephritis and pulmonary vasculitis in Behçet's disease. Am f Med 1979;66: nary vascu $1031-9$.

28 Durieux P, Bletry O, Huchon G, et al. Multiple pulmonary arterial aneurysms in Behcet's disease and Hughes-Stovin syndrome. Am $\mathcal{F}$ Med 1981;71:736-41.

29 Grenier Ph, Bletry O, Cornud F, et al. Pulmonary involvement in Behçet disease. AfR 1981;137:565-9.

30 Park JH, Han MC, Bettman MA. Arterial manifestations of Behçet disease. AfR 1984;143:821-5.

31 Efthimiou J, Johnston C, Spiro SG, et al. Pulmonary disease in Behçet's syndrome. $Q \mathcal{F}$ Med 1986;227:259-80.

32 Raz I, Okon E, Chajek-Shoul T. Pulmonary manifestations in Behcet's syndrome. Chest 1989;95:585-9.

33 Winer-Muram HT, Gavant ML. Pulmonary CT findings in Behçet disease. F Comput Assist Tomogr 1989;13:346-7.

34 Vansteenkiste J, Van-Haecke P, Demedts M. Long term treatment with cyclosporin and coumarin in pulmonary thromboembolic Behçet's disease. Monaldi Arch Chest Dis 1998;53:142-3.

35 Erkan F, Cavdar T. Pulmonary vasculitis in Behçet's disease. Am Rev Respir Dis 1992;146:232-9.

36 Hamuryudan V, Yurdakul S, Moral F, et al. Pulmonary artery aneurysms in Behçet's syndrome: a report of 24 cases. Br f Rheumatol 1994;33:48-51.

37 Tunaci A, Berkmen YM, Gökmen E. Thoracic involvement in Behçet's disease: pathological, clinical and imaging features. AfR 1995;76:155-7.

38 Tunaci M, Ozkokmaz B, Tunaci A, et al. CT findings of pulmonary artery aneurysms during treatment for Behçet's disease. AfR 1999;172:729-33.

39 Malik KJ, Weber SL, Sohail S, et al. MR. Hilar mass and papilledema on presentation, Chest 1998;113:227-9.

40 Erkan F. Pulmonary involvement in Behçet disease. Curr Opin Pulm Med 1999;5:314-8.

41 Numan F, Ilak C, Bermen T, et al. Behçet's disease: pulmonary arterial involvement in 15 cases. Radiology pulmonary arterial

42 Ahn JM, Im JG, Ryoo JW. Thoracic manifestations of Behçet syndrome: radiographic and CT findings in nine patients. Radiology 1995;194:199-203.

43 Baak M, Gül S, Yazgan Y, et al. A case of rapidly progressive pulmonary aneurysm as a rare complication of Behçet's syndrome. Angiology 1998;49:403-8.

44 Gebitekin C, Yilmaz M, Senkaya I, et al. Fatal hemoptysi due to pulmonary artery aneurysm in Behçet's disease. Eu f Vasc Endovasc 1997;13:233-6

45 Stricker H, Malinverni R. Multiple, large aneurysms of pulmonary arteries in Behçet's disease. Arch Intern Med 1989; 149:925-7.

46 Gibson RN, Morgan SH, Krausz T, et al. Pulmonary artery aneurysms in Behcet's disease. Br f Radiol 1985;58:79-82.

47 Almog Y, Polliack G, Elhalel M, et al. Bilateral pulmonary artery aneurysms in Behçet's disease. Eur Respir F 1993;6: artery an $1067-9$.

48 Sullivan EJ, Hoffman GS. Pulmonary vasculitis. Clin Chest Med 1998;19:759-76

49 Gunen H, Evereklioglu C, Kosar F, et al. Thoracic involvement in Behcet's disease and its correlation with multiple parameters Lung 2000;178:161-70.

50 Greene RME, Saleh A, Taylor AKM, et al. Non-invasive assessment of bleeding pulmonary artery aneurysms due to Behçet disease. Eur Radiol 1998;8:359-63.

51 Berkmen T. MR angiography of aneurysms in Behçet disease: a report of four cases. F Comput Assist Tomogr 1998, 22:202-6.

52 Celenk C, Celenk P, Akan H, et al. Pulmonary artery aneurysms due to Behçet's disease: MR imaging and digit subtraction angiography findings. AfR 1999;172:844-5.

53 Basoglu T, Canbaz F, Bernay I, et al. Bilateral pulmonary artery aneurysms in a patient with Behcet syndrome. Clin artery aneurysms in a pat Med 1998;23:735-8.

54 Gül A, Yilmazbayhan D, Büyükyabani N, et al. Organizing pneumonia associated with pulmonary artery aneurysms in Behcet's disease. Rheumatology 1999:38:1285-9.

55 Min J-K, Hong Y-S. Park S-H, et al. Bronchiolitis obliterans organizing pneumonia as an initial manifestation in patients with systemic lupus erythematosus. f Rheumato 1997;24:2254-7

56 Hasegeli Uner A, Rozum-Slota B, Katzenstein A-LA. Bronchiolitis obliterans-organizing pneumonia (BOOP)-like variant of Wegener's granulomatosis. A clinicopathologic study of 16 cases. Am $\mathcal{f}$ Surg Pathol 1996;20:794-801.

57 Lohr RH, Boland BJ, Douglas WW, et al. Organising pneumonia. Features and prognosis of crytogenic, secondary, and focal variants. Arch Intern Med 1997;157:1323-9.

58 Abid R, Hadj T, Abid F, et al. Superior caval syndrome, caused by chronic mediastinitis in Behçet's disease. $\mathscr{F}$
Radiol 1995;76:155-7.
59 Huong DLT, deGennes C, Papo T, et al. Pleuropulmonary manifestations of systemic vasculitis. Rev Med Interne 1996; 17:640-52

60 Kroger K, Ansasy M, Rudofsky G. Postoperative thrombosis of the superior caval vein in a patient with primary asymptomatic Behçet's disease. Angiology 1997;48:649-53.

61 Terzioglu E, Kirmaz C, Uslu R, et al. Superior vena cava syndrome together with multiple venous thrombosis. Clin Rheumatol 1998;17:176-7.

62 Okita Y, Ando M, Minatoya K, et al. Multiple pseudoaneurysms of the aortic arch, right subclavian artery and Surg 1998;28:723-6.

63 Nonaka K, Makuuchi H, Naruse J, et al. Pseudoaneurysm of aortic arch and rupture into pericardium, a case report of successful surgical management. fpn $\mathcal{f}$ Thorac Cardiovasc Surg 1998;46:772-6.

64 Abadoglu O, Osma E, Uçan ES, et al. Behçet's disease with pulmonary involvement, superior vena cava syndrome,
chyloptysis, and chylous ascites. Respir Med 1996;90:429-31.

65 Singer NG, McCune WJ. Update on immunosuppressive therapy. Curr Opin Rheumatol 1998;10:169-73.

66 Gross WL. New concepts in treatment protocols for sever systemic vasculitis. Curr Opin Rheumatol 1999;11:41-6.

67 Fresko I, Yurdakul S, Hamuryudan V, et al. The management of Behçet's syndrome. Ann Med Interne 1999;150: 576-81.

68 Koga T, Yano T, Ichikawa Y, et al. Pulmonary infiltrates recovered by FK506 in a patient with Behçet's disease. Chest 1993;104:309-11.

69 Sanchez-Burson J, Corzo JE, Marenco JL, et al. Thrombolytic therapy in pulmonary embolism of Behçet's disease. Acta Hematol 1996;96:181-3.

70 Mouas H, Lortholary O, Lacombe P, et al. Embolization of multiple pulmonary arterial aneurysms in Behcet's disease. multiple pulmonary arterial aneurysm
Scand $\mathcal{F}$ Rheumotol 1996;25:58-60.

71 Bradbury AW, Milne AA, Murie JA. Surgical aspects of Behçet's disease. Br $\mathcal{F}$ Surg 1994;81:1712-21.

72 Tuzun H, Hamuryudan V, Yildirim S, et al. Surgical therapy of pulmonary arterial aneurysms in Behcet's syndrome. Ann Thorac Surg 1996;61:733-5

73 Tuzun H, Besirli K, Sayin A, et al. Management of aneurysms in Behcet's syndrome: an analysis of 24 patients. Surgery 1997;121:150-6

74 de Montpreville VT, Macchiarini P, Dartevelle PG, et al. Large bilateral pulmonary artery aneurysms in Behcet's disease: rupture of the contralateral lesion after anaeurysmorrhaphy. Respiration 1996;63:49-51

75 Sakane T, Suzuki N, Nagafuchi H. Etiopathology of Behcet's disease: immunological aspects. Yonsei Med $\mathcal{f}$ 1997;38:350-8.

76 Gül A, Inanç M, Ocal L, et al. Familial aggregation of Behçet's disease in Turkey. Ann Rheum Dis 2000;59:622-5.

77 Mizuki N, Ota M, Kimura M, et al. Triplet repeat polymorphism in the transmembrane region of the MICA gene: a strong association of six GCT repetitions with Behçet disease. Proc Natl Acad Sci USA 1997;94:1298-303.

78 Ota M, Mizuki N, Katsuyama Y, et al. The critical region for Behçet's disease in the human major histocompatibility complex is reduced to a $46-\mathrm{kb}$ segment centromeric of HLA-B by association analysis using refined microsatellite mapping. Am f Hum Genet 1999;64:1406-10.

79 Mizuki N, Ota M, Katsuyama Y, et al. Association analysis between the MIC-A and HLA-B alleles in Japanese patients

80 Gül A, Hajeer AH, Worthington J, et al. Evidence for linkage of the HLA-B locus in Behcet's disease, obtained using the transmission disequilibrium test. Arthritis Rheum 2001;44: 239-40.

81 Gül A, Esin S, Dilsen N, et al. Immunohistology of skin pathergy reaction in Behçet's disease. Br f Dermatol 1995;

82 Hirohota S, Hashimoto T. Abnormal T cell responses to bacterial superantigens in Behçet's disease. Clin Exp Immunol 1998;112:317-24.

83 Mege J-L, Dilsen N, Sanguedolce V, et al. Overproduction of monocyte derived tumor necrosis factor $\alpha$, interleukin (IL) 6 , IL-8 and increased neutrophil superoxide generation in Behçet's disease. A comparative study with familial Mediterranean feve

84 Kaneko S, Suzuki N, Yamashita N, et al. Characterization of $\mathrm{T}$ cells specific for an epitope of human $60-\mathrm{kd}$ heat shock protein (hsp) in patients with Behcet's disease (BD) in Japan. Clin Exp Immunol 1997;108:204-12.

85 Freysdottir J, Lau S-H, Fortune F. $\gamma \delta$ T cells in Behçet's disease (BD) and recurrent aphthous stomatitis (RAS). Clin Exp Immunol 1999;118:451-7.

86 Frassanito MA, Dammacco R, Cafforio P, et al. Th1 polarization of the immune response in Behçet's disease. Arthritis Rheum 1999;42:1967-74

87 Sugi-Ikai N, Nakazawa M, Nakamura S, et al. Increased frequencies of interleukin-2- and interferon-gammaproducing $\mathrm{T}$ cells in patients with active Behcet's disease. Invest Ophthalmol Vis Sci 1998;39:996-1004.

88 Niwa Y, Miyake S, Sakane T, et al. Auto-oxidative damage in Behçet's disease endothelial cell damage following the elevated oxygen radicals generated by stimulated neutrophils. Clin Exp Immunol 1982;49:247-55.

89 Takeno M, Kariyone A, Yamashita N, et al. Excessive function of peripheral blood neutrophils from patient with Behcet's disease and from HLA-B51 transgenic mice. Arthritis Rheum 1995;38:426-33. 
90 Sensi A, Gavioli R, Spisani S, et al. HLA B51 antigen associated with neutrophil hyperreactivity. Dis Markers 1991;9. ciated with 327 .

91 Esin S, Gül A, Hodara V, et al. Peripheral blood T cell expansions in patients with Behçet's disease. Clin Exp Immunol 1997;107:520-7.

92 Pervin K, Childerstone A, Shinnick T, et al. T-cell epitope expression of mycobacterial and homologous human 65-kilodalton heat shock protein peptides in short term cell lines from patients with Behçet's disease. F Immunol 1993; 151:2273-82.

93 Direskeneli H, Eksioglu-Demiralp E, Yavuz S, et al. T cell responses to $60 / 65 \mathrm{kDa}$ heat shock protein derived peptides in Turkish patients with Behcet's disease. 7 Rheumatol 2000;27:708-13.

94 Yamashita N, Kaneoka H, Kaneko S, et al. Role of $\gamma \delta \mathrm{T}$ lymphocytes in the development of Behçet's disease. Clin Exp Immunol 1997;107:241-7.
95 Hasan A, Fortune F, Wilson A, et al. Role of $\gamma \delta \mathrm{T}$ cells in the pathogenesiss and diagnosis of Behçet's disease. Lancet pathogenesiss and

96 Stanford MR, Kasp E, Whiston R, et al. Heat shock protein peptides reactive in patients with Behçet's disease are uveitogenic in Lewis rats. Clin Exp Immunol 1994;97:226-31.

97 Yazici H, Tuzun Y, Pazarli H, et al. Influence of age of onset and patient's sex on the prevalence and severity of manifestations of Behçet's syndrome. Ann Rheum Dis 1984;43: t83-9.

98 Dilsen N, Konice M, Aral O, et al. Risk factors for vital organ involvement in Behçet's disease. In: Wechsler B, Godeau P, eds. Behçet's disease. Amsterdam: Excerpta Medica 1993:165-9.

99 Ergun T, Gürbüz O, Dogusoy G, et al. Histopathologic features of the spontaneous pustular lesions of Behçet's disease. Int f Dermatol 1998;37:194-6.

\section{1st Asia Pacific Forum on Quality Improvement in Health Care}

\section{Three day conference}

\section{Wednesday 19 to Friday 21 September 2001 \\ Sydney, Australia}

We are delighted to announce this forthcoming conference in Sydney. Authors are invited to submit papers (call for papers closes on Friday 6 April), and delegate enquiries are welcome.

The themes of the Forum are:

- Improving patient safety

- Leadership for improvement

- Consumers driving change

- Building capacity for change: measurement, education and human resources

- The context: incentives and barriers for change

- Improving health systems

- The evidence and scientific basis for quality improvement.

Presented to you by the BMJ Publishing Group (London, UK) and Institute for Healthcare Improvement (Boston, USA), with the support of the the Commonwealth Department of Health and Aged Care (Australia), Safety and Quality Council (Australia), NSW Health (Australia), and Ministry of Health (New Zealand).

For more information contact: quality@bma.org.uk or fax +44(0)20 73836869 